\title{
New Media and Strategy Research Towards a Relational Agency Approach
}

\author{
Gulbrandsen, Ib T.; Plesner, Ursula; Raviola, Elena
}

Document Version

Accepted author manuscript

Published in:

International Journal of Management Reviews

DOI:

10.1111/ijmr.12213

Publication date:

2020

License

Unspecified

Citation for published version (APA):

Gulbrandsen, I. T., Plesner, U., \& Raviola, E. (2020). New Media and Strategy Research: Towards a Relational Agency Approach. International Journal of Management Reviews, 22(1), 33-52.

https://doi.org/10.1111/ijmr.12213

Link to publication in CBS Research Portal

\section{General rights}

Copyright and moral rights for the publications made accessible in the public portal are retained by the authors and/or other copyright owners and it is a condition of accessing publications that users recognise and abide by the legal requirements associated with these rights.

Take down policy

If you believe that this document breaches copyright please contact us (research.lib@cbs.dk) providing details, and we will remove access to the work immediately and investigate your claim. 


\title{
New Media and Strategy Research: Towards a Relational Agency Approach
}

\author{
Ib T. Gulbrandsen, Ursula Plesner, and Elena Raviola
}

Journal article (Accepted manuscript*)

\section{Please cite this article as:}

Gulbrandsen, I. T., Plesner, U., \& Raviola, E. (२०२०). New Media and Strategy Research: Towards a Relational Agency Approach. International Journal of Management Reviews, 221), 33-52. https://doi.org/10.11l1/ijmr.12213

This is the peer reviewed version of the article, which has been published in final form at DOI:

https://doi.org/10.1111/ijmr.12213

This article may be used for non-commercial purposes in accordance with

Wiley Terms and Conditions for Self-Archiving

* This version of the article has been accepted for publication and undergone full peer review but has not been through the copyediting, typesetting, pagination and proofreading process, which may lead to differences between this version and the publisher's final version AKA Version of Record.

Uploaded to CBS Research Portal: July २०२० 


\section{NEW MEDIA AND STRATEGY RESEARCH: TOWARDS A RELATIONAL AGENCY APPROACH}

\section{SUMMARY}

A rapidly growing body of literature focuses on the relationship between new media and strategy, and offers some recommendations regarding appropriate strategic actions in relation to new media. This article systematically reviews 130 articles with a focus on their diagnoses and the directions they give strategists in relation to the role of new media in strategy. These diagnoses and directions rely on and contribute to different conceptualizations of new media. The article identifies four main ways of conceptualizing new media in the literature: as elements in an increasingly turbulent strategic environment, as changing the role of strategists, as tools for strategically engaging stakeholders, and as both increasing and decreasing the control necessary for strategy making. These conceptualizations are based on often-implicit assumptions about 'agency' in strategy: new media are seen either as forces influencing strategy or as tools in the hands of humans, who are portrayed as the agents of strategy. In both cases, new media are black-boxed, such that their specific properties and ways of becoming embedded in particular contexts are rarely examined. After discussing these assumptions and a limited number of studies that challenge them, the article develops an approach to strategy and new media based on a relational understanding of agency, a focus on technological affordances and a methodological approach that assumes that new media and strategy are assemblages of human and non-human elements. We argue that future research building on a theoretical framework that integrates agency, affordances and assemblages will advance our knowledge of strategy making in ways that do not take new media for granted and ways that are attentive to different kinds of agency. 


\section{INTRODUCTION}

In this paper, we argue for the need to pay closer attention to the question of agency in strategy research on new media. We draw on Manovich's (2001) definition of new media as software, hardware and informational phenomena. Over the past decade, new forms of software (e.g. Google, Facebook and Wikipedia), hardware (e.g. smartphones, tablets and touchscreens) and informational phenomena (e.g. hyperlinking, collaborative editing and geotagging) have made technology usage more dynamic, applications more interactive, and peer-to-peer communication and exchange more direct (Gulbrandsen and Just, 2011; Plesner and Gulbrandsen, 2015). In this interpretation, new media can be thought of as a subset of the broader category of digital technologies, which also includes production technologies, robotics and artificial intelligence. The concept of new media points to the 'mediation' aspect of digital technologies by emphasising their transformative impact on messages, experiences and interactions.

Since the introduction of contingency theory (e.g. Woodward, 1958; Thompson and Bates, 1957), technology has been considered a determining factor for organizational activities, including strategy (see, e.g., Abell 1980; Abernathy, 1978; Anderson and Tushman, 1990; Cooper and Schendel, 1976; Foster, 1985; Maidique and Patch, 1988; Porter 1983; Tushman and Anderson, 1986). More contemporary scholarship on new media also views technology as important for strategy in such areas as ecommerce (e.g. Buhalis, 2004; Kim et al., 2004), stakeholder relations (e.g. Straker and Wrigley, 2016; Vallaster and von Wallpach, 2013), intra-organisational coordination (e.g. Guinan et al., 2014; Andersen and Foss, 2005), management (e.g. Koushik et al., 2009; Esteves, 2008), production (e.g. Lang et al., 2015; Arakji and 
Lang, 2007) and communication (e.g. Hanna et al., 2011; Lettice and Brayshaw, 2007). New media have implications not only for organisations' strategic relationships with their customers and users (e.g. Segars and Kohut, 2001; Advani and Choudhury, 2001; Stace et al. 2005) but also their information sources (e.g. Trantopoulos, Krogh and von Wallin, 2017), ways of analysing strategic environments (e.g. Lettice and Brayshow, 2007) and conceptions of strategic necessities (e.g. Molteni and Ordanini, 2003). In short, new media has transformed the process of strategy making - they are used by strategists, are found in boardrooms and executive suites, and have opened up the strategy process to new participants.

This article contributes to the exploration of the role and effects of new media in strategy by reviewing contributions to the field published in the top-20 ABS-listed journals from 2000 to 2018 . We analyse the literature with a focus on the 'diagnoses' scholars provide regarding the new conditions for strategy work and on the 'directions' they suggest strategists should take on the basis of those diagnoses. We aim to tease out the assumptions about new media on which the diagnoses and directions rest. By "investigat[ing] and challeng[ing] existing assumptions in a field" (Alvesson and Sandberg, 2014, p. 982), we pave the way for alternative routes of understanding.

Our analysis reveals that strategy scholarship on new media generally treats new media as rather fixed entities. They tend to be black-boxed, and treated as 'forces' or 'tools' that have implications for strategy work. Most articles published on strategy and new media in the past twenty years fail to investigate how new media are constructed within and outside a given organisation, or what ideologies they carry. 
Likewise, the extant research rarely closely examines the properties or agency of new media. From our perspective, this is a significant gap in the literature.

To go beyond the view of new media as simply drivers of change, tools or mediators (Haefliger et al. 2011), we propose an alternative theoretical route to understanding strategy and new media: 1) relying on a relational view of agency, 2) using the analytical concept of affordances and 3) adopting an agnostic and symmetrical methodology for tracing strategy-making assemblages. We are inspired by recent scholarship on technology in organisation and management (see, e.g., Czarniawska and Hernes 2005; Leonardi and Vaast 2017; Orlikowski 2007; Mazmanian et al. 2014) as well as strategy as practice (see, e.g., Jarzabkowski 2005; Jarzabkowski and Spee 2009; Johnson et al. 2007; Whittington 2006) and contributions to the British Journal of Management's special issue on materializing strategy and strategizing materials (see Dameron, Lê and LeBaron 2015). Such contributions, which have an eye for the interwovenness of the material and the social, offer innovative and fruitful insights into strategy development and implementation. However, the contributions about new media have rarely focused on strategy, while those about strategy have rarely focused on new media. This implies that the relationship between new media and strategy has not been sufficiently theorized in these traditions (see, e.g., Haefliger et al. 2011 or Whittington 2015 for exceptions). We address this gap by proposing an alternative route of understanding the relationships between strategy and new media as one in which strategy depends on how different configurations of actors (strategists, new media and other actors) create different possibilities for strategic action. 
The rest of the paper is structured as follows. First, we describe our review method, including journal selection, article search and analysis of the final sample. We then present our analysis of the literature, which is divided into four main themes. Based on the findings of our analysis, we discuss the main gaps in the literature with a particular focus on the issue of agency and we propose a research agenda based on a relational view of agency.

\section{REVIEW METHOD}

Inspired by Crane et al. (2016), we chose a thematically driven method of selection, and decided to include articles from different streams of business and management literature, including strategy, organisation, general management and information systems (IS). The topic of strategy and new media has been addressed in each of these domains. As Crane et al. (2016) note, the theorization of a given theme may rest upon various management disciplines. Crane et al. (2016) turned to five different disciplines, which they argued offered rich and diverse avenues for exploring their topic. In our case, we found that strategy, organisation, general management and IS speak to each other through cross-references, and that they each contribute different approaches to strategy and new media. The strategy literature often focuses on new media as either a threat or an opportunity, the organisation and management literature typically examines organisational dimensions of new media usage, and IS research tends to study implementations of particular types of new media in organisations. We chose an extensive approach because all of these perspectives are useful for exploring current thinking about strategy and new media, but we do not attempt to account for how this phenomenon is touched upon in disciplines other than those mentioned above. 


\section{SELECTION OF JOURNALS}

The basis of our review is a sample of journal articles that provide insights into each of the disciplines listed above. Like Crane et al. (2016), we sought to build a broad representative sample by selecting 20 journals within each research stream. As our purpose is to examine dominant assumptions about strategy and new media, we based our primary journal selection on impact factors. We used the ABS list to select the 20 most impactful journals according to their rankings within our areas of interest: strategy, organisation studies, general management and information management. ${ }^{\mathrm{i}}$ We narrowed our sample by removing journals that dealt with specialized topics. ${ }^{\text {ii }}$

Published academic articles are argued to make the best foundation for a literature review (David and Han 2004; Wales and Gupta 2011), especially if the review is, for instance, about theory testing. However, we also included practitioners' journals because we are interested in assumptions about strategy and new media in both theory and practice, and we consider them intertwined. Strategy scholarship is often practitioner oriented, and strategy-related thinking often relies on ideas and models from the scholarly literature. We therefore added practitioners' journals (e.g. Harvard Business Review and Journal of Business Strategy) to the selection based on their impact in terms of readership.

We chose to cover a specific time period (a similar strategy is found in Crane et al. 2016), namely from 2000 to 2018. ${ }^{\text {iii }}$ This period represents the time passed since the burst of the dotcom bubble. In this period, organisations saw an upsurge in new media, which prompted renewed investigations of the role of technology in both practice and academia. 
Our journal-selection strategy resulted in 61 journals (see Table 1 and Appendix 1 for details).

\begin{tabular}{|l|l|}
\hline ABS subject & Journals \\
\hline General management, ethics and social & 17 \\
\hline Organisation studies & \\
\hline Strategy & 16 \\
\hline Information management & 12 \\
\hline
\end{tabular}

Table 1. Number of journals reviewed

\section{SEARCH STRATEGY}

To produce a sample of articles on the basis of the selected journals, we used the databases EBSCOhost, ScienceDirect, Springerlink, Business Source Complete, Taylor and Francis Online, JSTOR, Wiley, Sage, and Emerald Insight. All of the relevant journals from the ABS list are not searchable in any one database, so it was necessary to find a matching database for each journal. Due to the technical limitations of the search engines, we conducted the search of each journal in three steps: in the journals' abstract, keyword and title fields. ${ }^{\text {iv }}$

As keywords, we used the term 'strategy' plus at least one of the following: 'new media', 'information and communication technology', 'ICT', 'social media', 'Web 2.0', 'enterprise social media', 'social software', 'blogging' or 'digital'. 'Strategy' (and 'strate*') were included because of our interest in exploring how conceptions of strategy and strategy making evolve in light of digital technology developments. We 
consider 'new media' an umbrella term that covers software, hardware and informational phenomena. The other terms we combined with 'strategy' are all aspects or types of new media, or terms used to denote some aspect of new media. 'Information and communication technologies' and 'ICT' are umbrella terms similar to 'new media' but their use is declining. They were included because they have frequently been used in the literature to describe software, hardware and informational phenomena. 'Social media', 'Web 2.0', 'enterprise social media', 'social software' and 'blogging' were included because they point to another generation of new media in which user involvement and interactivity take centre stage. Finally, 'digital' was included because it is frequently invoked to denote 'new technologies', including 'new media'.

To ensure 'substantive relevance' (Wales and Gupta 2011) and avoid random selection of material, we used a systematic approach inspired by David and Han (2004) (see Appendix 2), which resulted in a number of abstracts. Prior to reading the abstracts, we defined a set of criteria for inclusion (David and Han 2004). First, when 'strategy' was mentioned, the article was only included if the article was about organisational strategy or strategy making. If 'strategy' was only used in a limited sense (e.g. communication strategies) or on a macro level (e.g. national strategies), the article was excluded. Second, both empirical and more conceptual articles were included because both contribute to an understanding of strategy and new media. Book reviews and executive summaries were not included. With a large sample of articles, it is necessary to eliminate 'substantially irrelevant' articles (Newbert 2007). Given the above inclusion criteria, we excluded a number of articles that had little to 
do with strategy and new media. ${ }^{\mathrm{v}}$ The search strategy and selection criteria resulted in a sample of 130 articles when corrected for duplicates (see Appendix 3).

\section{METHOD OF ANALYSIS}

The 130 articles were analysed in a two-step process. First, each article was examined with a focus on the following questions:

1) What changes are brought about by new media?

2) What do these changes mean for strategy?

3) Who is active in formulating and implementing strategy?

The first two questions point to the kinds of diagnoses authors offer regarding the relationship between strategy and new media, and the implications they believe this relationship has. The last question is aims to explicitly identify the actors in strategy making or where agency is located. See Appendix 3 for an overview of all of the articles and the results of this part of the analysis.

The second part of the analysis focused on identifying wider themes describing how strategy and new media have been treated in research based on the initial coding and analysis. The themes were inductively derived from a thorough reading of the results of the first part of the analysis. We identified four main themes. First, the most recurrent theme revolved around new media as disruptive forces in an increasingly turbulent environment that erode traditional sources of competitive advantage and create new ones. Second, many articles focused on how new media change the role of strategists. A third concern was the way in which new media were used for the engagement of strategic stakeholders. The final was the issue of strategic control. Themes could overlap in single articles or a single theme could be a primary focus of an article. In our analysis, we treat the themes as four different patterns in how the 
literature portrays the relation between new media and strategy, although they may overlap at times. We describe and explore the evolution of each theme over time, and highlight how new media are conceived of in relation to strategy (diagnosis), the implications of these diagnoses in terms of strategy (directions), and the assumptions about new media that underlie the diagnoses and directions.

\section{A TURBULENT ENVIRONMENT FOR STRATEGY}

The biggest discussion topic in the literature on new media and strategy concerns the increased turbulence and dynamism in the environment, for which new media are held responsible. The literature warns established companies about the necessity of renewal and, for the most part, concentrates on identifying new ways of competing. This issue has been on the scholarly agenda since the early 2000s (e.g. van Wegberg et al., 2001) and it remained of interest to researchers throughout the focal period (e.g. Pagani 2013; Gandia and Parmentier 2017). Different aspects of environmental turbulence have been in focus in parallel literature streams, where they are identified as both positive (e.g. Nylén and Holmstrom 2015; Dongback 2017) and negative (Singer, 2006). The literature within this stream generally assumes that new media are external forces to which companies must adapt.

\section{DIAGNOSIS: NEW GROUNDS FOR COMPETITIVE ADVANTAGE}

Many articles start from the observation that the environment in which companies operate has become more turbulent and competition has become fiercer (Mcafee and Brynjolfsson, 2008). This turbulent environment is what we called the 'New Economy' around the beginning of the 2000s (van Wegberg et al., 2001). New media are diagnosed as changing the foundations for competitive advantage and creating 
new ones. This stream of literature highlights three aspects of new media related to changes outside the company and strategic renewal within its boundaries. First, the value chain is being disrupted and reconfigured. Second, innovation has become what will ultimately sustain companies' competitive advantages. Third, it is possible to produce a significant amount of digital data that might be of strategic importance.

Many scholars ascribe the shifting bases for competitive advantage to the disruption of the value chain, which was traditionally built vertically around B2B relations. In the early 2000s, a main scholarly observation was that value chains across industries had been disintermediated by new media. In other words, certain actors became obsolete because producers and consumers could interact directly. New forms of value-chain integration emerged as a consequence of what Mol et al. (2005) refer to as "value chain envy" and certain functions became more attractive in terms of value creation. The roles of some intermediaries between producers and consumers were reconsidered as were traditional strategies (Kim et al. 2004). This was the case, for example, in the brokerage (Kalakota and Konsynski 2000) and music industries, which drew considerable attention in the scholarly literature (Mol et al. 2005). Thereafter, the "e-" phenomena - such as e-business, e-commerce and e-strategy became popular among scholars and managers in numerous industries (see, e.g., Buhalis 2004; Kim et al. 2004; Stace et al. 2004). Several years later, the discussion on the changing value chain shifted to "collaboration" (Tsekouras et al. 2013; Pagani 2013) and "value creation in networks" (Grover and Kohli 2013; Gandia and Parmentier 2017). Businesses from otherwise distinct industries converged into newly emerging fields, and competition and relations were configured in new ways. Consequently, strategies needed to be rethought (Dongback 2017). 
One strategically significant element of the disintermediation trend and the emergence of "e-" phenomena was the possibility to produce and use data about consumption and consumers. This generated widespread interest in "big data" analyses. As early as 2003, Molteni and Ordanini wrote that digital consumption in the music industry had made it possible to collect consumer data and use it to better understand consumption patterns. Digital data have become the basis for new ways of understanding and dealing with the market. They allow for new forms of analytics and for market resegmentation (Singer 2006; Rosenberger et al. 2009; Xu et al. 2016; Miah et al. 2017). Moreover, they can be used to detect early signs of new trends (Glassey 2009) and to construct warehouses of customers' feedback data (García-Moya et al. 2013). Business intelligence is also being enhanced by digital data, which improves strategy making in relation to, for instance, mergers and acquisitions (Lau et al. 2012) or strategic goal setting (García-Moya et al. 2013). Focusing on the 'data revolution' created by new media, authors like Kallinikos and Constantiou (2015) argue that new media have fundamentally changed the context of strategy by creating new lay publics and new recordings of social data. Big data is portrayed as an important contextual factor for strategy - one that can create opportunities if strategy makers know how to use it.

Another aspect of this diagnosis is the increasingly strategic importance of innovation. In the new turbulent environment, innovation is expected to lead to and sustain new competitive advantages (Nylén and Holmstrom 2015; Dongback 2017). Old strategic thinking becomes obsolete and disaligns the organization from fastchanging markets (Day and Schoemaker 2016; Yeow et al. 2017). El Sawy et al. 
(2010) refer to IT innovation as a necessary reaction to turbulent environments. This diagnosis applies to large corporations, as in Setia et al.'s (2013) study of banks, as well as small and medium enterprises, as shown by Gagliardi (2013).

\section{DIRECTIONS: REINVIGORATE CLASSICAL STRATEGY THINKING}

The strategy literature that describes new media as creating new foundations for competitive advantage proposes a need for continual renewal of traditional generic strategies and strategy-making practices. The implications for strategy are mostly expressed in terms of 'differentiation', 'control', 'value appropriation' and 'strategic choices and decisions'. Somewhat paradoxically, the diagnosis of the profound changes brought about by new media in the environment and within companies seems to reaffirm classical strategy principles and practices.

This is evident in analyses of the consequences of digital data production for strategy. With some exceptions, most scholars view digital data as a strategic resource that helps increase control over the market. Researchers report that strategists use digital data to refine their market segmentation (e.g. Molteni and Ordanini, 2003; Rosenberg et al., 2009; Luo et al., 2015), to make scenario-planning and strategic decisionmaking processes more accurate (e.g. Oliver et al., 2018), to differentiate and customize their offerings (e.g. Quinton and Harridge-March, 2006; Glassey, 2009), and to increase the information gathered on their competitors in order to outperform them (e.g. Lau et al., 2012; Grover and Kohli, 2013; Garcia-Moya et al., 2013).

The dominant message of this stream of literature is that turbulent environments can be handled through the development of an even more accurate and informed rationality. The dynamic digital capabilities that companies are urged to develop 
appear to be super-intelligent versions of existing dynamic capabilities (El Sawy et al., 2010; Setia et al., 2013; Day and Schoemaker, 2016). However, there are exceptions to the inclination to cultivate traditional strategic concepts and ways of thinking. Kallinikos and Costantiou (2015) write that the 'big data revolution' is forcing strategists and scholars to question some of the traditional prescriptions stemming from the strategic-planning discipline. They propose that organisations are moving away from forecasting, and becoming better at leveraging available and constantly changing data in a more emergent way, which they argue works better in the non-hierarchical, open platforms that characterize new media.

\section{ASSUMPTIONS ABOUT NEW MEDIA}

In this stream of literature, new media are portrayed as independent external forces that disintermediate the value chain (Mol et al., 2005; Kim et al., 2004), create new markets (Singer, 2006; Rosenberger et al., 2009; Miah et al., 2017), make markets change quickly (Day and Schoemaker, 2016; Yeow et al., 2017) and introduce a new logic of competition and collaboration (Tsekouras et al., 2013; Pagani, 2013; Grover and Kohli, 2013). In other words, new media are described as doing something to companies to which companies must adapt through, for instance, e-strategies (Buhalis, 2004; Stace et al., 2004). Agency, which is defined as the capacity to act, is assumed to belong to new media, as new media are ones disrupting, making and creating conditions to which companies and strategists must react. In other words, they determine companies' (need for) strategic action.

\section{THE CHANGING ROLE OF STRATEGISTS}

A second theme in the literature about new media and strategy is that the role of strategists is being transformed. New media are portrayed as allowing for two-sided 
communication, which means that stakeholders who are traditionally excluded from strategy making might be included, and that relationships between strategists and stakeholders might change. Although a few articles were published on this issue between 2005 and 2009, scholars mostly began to realize and explore changes in strategists' roles in organisations after 2010. In this stream of literature, new media are generally assumed to be independent forces that change the conditions and practices of strategy from within the organization.

\section{DIAGNOSIS: CHANGING COMMUNICATION}

A common observation across these studies is that new media change communication practices in organisations among both managers and employees. This stream of literature diagnoses new media as carrying a new logic for strategists' work, driven by 'dialogic communication' and 'participation', and as encouraging 'new relations between employer and employees'. The new logic is portrayed as having implications for various strategic organisational aspects: the communication of strategy, the involvement of employees in that strategy, coordination in the organisation, and the creation and sharing of knowledge.

Scholars highlight that the new media logic implies more open communication between management and external stakeholders (Granados and Gupta 2013), and between management and employees. For example, Koushik et al. (2009) portray new media as fostering an organisational reality marked by 'community and sharing' through more networked and dialogic communication infrastructures and practices. This, they suggest, should inspire new forms of management, especially in relation to the development of strategy, that move away from hierarchies toward a networked understanding of organisations. Esteves (2008) argues that new media give employees 
the possibility - and expectation - to more actively participate in strategic processes. Haefliger et al. (2011) find that new media can empower creative, independent individuals and, thereby, trigger indeterminate and uncertain reactions and creations that support or oppose management's thinking.

Another consequence of changing communication by means of new media is the transformation of organisational coordination. New media are portrayed as allowing for better collaboration and coordination among employees, such as managers in multinational enterprises (Andersen and Foss 2005). Guinan et al. (2014) emphasize that improved collaboration among employees increases innovation abilities, while other scholars concentrate on collaboration around strategic decision making (Whittington 2015; Sasaki 2011). Another group of studies explores how new media might serve as knowledge-sharing platforms for employees (e.g. Archer-Brown and Kietzmann 2018) and elaborate on new media's consequences for knowledge-sharing in organisations.

\section{DIRECTIONS: REVISIT BOUNDARIES AND TRUST}

Based on the diagnosis that new media transforms communication and, thereby, the role of strategists, scholars point to a need for renewed concern about 'boundaries' and 'trust'. While these are classic themes in the strategy literature, this stream of research emphasizes that the new communication practices represent new ways for strategists to create or reinforce boundaries, and to build trust both inside and outside the organisation. In the most prescriptive literature, new technologies, like 'blogs', 'wikis' and 'telework', are suggested as ways of building organisational communities and increasing participation in strategic and developmental activities, or at least as ways of developing communication related to these activities (e.g. Esteves 2008). 
As new media are seen as facilitating coordination among employees from different parts of the organisation (Guinan et al. 2014; Andersen and Foss 2005), it becomes increasingly important for strategists to shape, create and reinforce boundaries. New media can allow for geographical and functional boundaries to be reshaped or crossed (Guinan et al. 2014), or for new communities shaped by management to emerge (Haefliger et al. 2011). In addition, as new media allow for open communication within the organisation and for interaction and communication with external stakeholders, strategists must deal with organisational boundaries. Scholars have warned that strategists need to find a balance between open and closed boundaries, and between user-generated content and organisation-generated content (Huang et al. 2015).

In relation to new communication dynamics, trust becomes a key concern for strategists. Huang (2013), for example, focuses on how leaders can increase employees' trust by using the new rhetorical possibilities offered by new media, like multivocality, the increasing reach and richness of communication, and opportunities for content co-production. Others focus on the visualization possibilities offered by new media, which can change both the medium and the content of the strategic message. Pictures or graphics are shown to communicate clearer strategic messages, to encourage dialogue and inclusiveness among employees, and to facilitate the ability to remember a strategy (Lettice and Brayshaw 2007). This stream of literature is mostly oriented towards the positive effects of using new media on both internal and external stakeholders' trust. 
A number of positive organizational effects are associated with the increase in trust that arises from the use of new media. One is improved knowledge sharing in organizations. The enhancement of trust through new media's characteristics of open communication, transparency and participation allows for better knowledge sharing through new media platforms (Paroutis and Al Saleh, 2009). Another is improvements in strategic decision making. For example, Bennis (2013) shows that direct interactions between leaders and organizational members and between company members and external stakeholders build trust and transparency around leadership. This transparency might, in turn, help strategists make better strategic decisions by providing them with direct access to information from strategic stakeholders (Bennis, 2013).

\section{AsSUMPTIONS ABOUT NEW MEDIA}

In this stream of literature, new media are portrayed as independent forces that change the conditions and practices of strategy from within the organization: they allow for dialogue between managers and workers (Esteves, 2008; Sasaki, 2011), and they make coordination and collaboration easier and more efficient (Paroutis and $\mathrm{Al}$ Saleh, 2009; Guinan et al., 2014; Archer-Brownand Kietzmann 2018). Similar to the previous stream of literature, new media are described as doing something to organisations, changing organisational roles and processes, and creating new imperatives for strategy work. Thus, new media is assumed to have agency, as they can change the role of the strategist. In other words, new media determine the constraints and possibilities of strategic action to which strategists must adapt by, for instance, balancing boundaries (Guinan et al., 2014) and upholding trust (Bennis, 2013). 


\section{STRATEGIC ENGAGEMENT OF STAKEHOLDERS}

A third stream of literature portrays new media as tools that companies can use to engage stakeholder groups in new ways. Although most of the literature focuses on consumers, some studies examine the engagement of investors, other businesses and citizens (e.g. in relation to the formulation of public policy). In our review, we found studies concerned with stakeholders' engagement published as early as 2001 (Advani and Choudhury 2001; Segars and Kohut 2001), but the scholarly relevance of this theme increased significantly after 2010. This is hardly a surprise, as social-media platforms like Facebook, Twitter and Instagram began gaining momentum at that time, becoming an everyday reality for organisations and researchers alike. In this stream, new media are generally portrayed as tools that are deliberatively and instrumentally used by organisations and strategists, rather than as forces that determine strategy work. As such, agency is assumed to be solely on the side of the strategists using these tools.

\section{DIAGNOSIS: ENABLE COMMUNITY AND PARTICIPATION}

Scholars in this stream of literature see new media as tools for engaging strategic stakeholders in different ways. The vast majority of studies focus on the positive effects of engagement in the company's strategy and strategy making, while only a handful stress the potential risks. New media are portrayed as tools through which companies and stakeholders can receive and exchange information, build communities, and co-create in new ways. These three activities represent a continuum of increasing engagement, and they seem to occur chronologically as new platforms are introduced and new media are increasingly integrated into people's everyday lives. 
The first aspect - new media making it possible to receive and exchange information in new ways - is particularly evident in articles from the early 2000s in which interaction was viewed as central. Segars and Kohut (2001), for example, studied how CEOs effectively used the internet to communicate with investors. Others examined how interactions between companies and consumers enhanced customers' experiences (Advani and Choudhury 2001; Stace et al. 2005) and created new possibilities for customization (Killian and McManus 2015). In a relatively recent paper, Barros (2014) developed the idea that new media offer a way for companies to bypass traditional media and directly manage their own legitimacy. This also touches on the need to control corporate reputation and legitimacy when engaging with stakeholders.

The second aspect - new media making it possible to build communities - is a more recent topic of scholarly concern. It primarily relates to strategic brand management through engagement in online, multi-stakeholder communities (e.g. Vallaster and von Wallpach 2013). Scholars have also stressed the importance of building emotional bonds through new media. For example, Shih et al. (2014) studied how social-media interactions involving emotions allow companies to build fan bases, which are of strategic importance. Straker and Wrigley (2016) insist on the importance of emotional engagement for consumer loyalty. One way of emotionally engaging stakeholders in communities built around organisations is for leaders to use socialmedia tools, especially Facebook and Twitter, to engage with followers and create mass intimacy with their stakeholders. 
The third aspect - new media making it possible to increase participation - has also come into focus in recent years. It relates to the possibilities stakeholders have to become actively involved in different parts of the previously exclusive organisational life and to the opportunities managers have to activate stakeholders. In this realm, we find the development of "co-" and "open" strategies, such as stakeholder participation through the co-creation of marketing content (Hanna et al. 2011) as well the coproduction of actual products (Arakji and Lang 2007; Lang et al. 2015). The practices of open innovation and co-production are inspired by the open-source movement (Gençer and Oba 2011), although they are also applied by established companies like Dell and Starbucks (Dong and Wu 2015). A third area of participation is open strategy making. In his commentary on the massification of strategy, Whittington (2015) describes open strategy making as a practice of openly and massively involving employees and other crowds in a new way. The leading organisations in this area have been new media companies, like Wikipedia and Creative Commons, which have engaged crowds and communities to handle strategic tasks - not only digital innovation but also strategy making itself (Dobusch and Kapeller 2017). Baptista et al. (2017) note that open strategy making requires new organisational capabilities. When strategies become more transparent and inclusive, managers need to develop reflexive skills as a new basis for making and communicating strategy to their stakeholders and strategy-making participants.

In the development of the diagnosis in this section, different images of stakeholders have emerged. Descriptions of increased opportunities to receive and exchange information presuppose that stakeholders are individuals who are able to interact with companies. In accounts of community building, stakeholders are framed as 
community members. Finally, stakeholders may be conceptualized as crowds masses of individuals who do not form a specific, identifiable community. The sheer multiplicity of stakeholder types in the literature testifies to their increasing significance in and around strategy processes.

\section{DIRECTIONS: TAKE STAKEHOLDER DEMANDS INTO ACCOUNT}

This stream of literature identifies new media as allowing for new ways of engaging stakeholders. Stakeholders - most often customers and consumers - acquire strategic roles in three ways. First, they are at the centre of new business models. Second, they increase the strategic importance of the marketing function. Third, they demand active legitimacy work from organizations.

The redesign of business models is mostly discussed in the practitioner-oriented literature, where devoted strategic stakeholders are in focus. One example is Hienerth et al. (2011), who argue that companies can attract and engage users through usercentred business models based on social software. They end the article with seven steps that organisations should take in order to ensure mutually beneficial emotional engagement. Other examples along the same lines are the crowd-based business models described by Täuscher (2017) and the fan-based business model based on social media discussed by Shih (2014).

The second direction implied by this diagnosis involves the role of marketing in strategy making. Many scholars who observe and praise the strategic engagement of stakeholders through new media conclude their analyses by encouraging companies to integrate marketing and communication into the core of their strategy making (Stace et al., 2005; Hanna et al., 2011; Lovejoy and Saxton, 2012; Akma and Mishra, 2017). 
Some scholars recommend the introduction of new strategic executive roles specifically dedicated to engaging stakeholders, like the Ringmaster (Spenner, 2010) or the community manager (Armano, 2010). The new strategic role of marketing - the delivery of expertise with regards to relationships with customers and consumers - is also justified by strategic concerns regarding the corporate reputation. This echoes concerns about trust associated with the diagnosis of new media as changing strategists' ways of communicating. However, in this case, the discussion is primarily focused on the risk that companies might succumb to external legitimacy crises (Veil et al., 2012; Castelló et al., 2016; Baptista et al., 2017).

The third implication of engaging strategic stakeholders described in the literature is that legitimacy needs to be managed in new ways. Schwartz (2005) encourages strategy communication through blogs open to employees and external stakeholders, although this might expose the company to critique. He claims that the risks of engaging in blogging and other forms of transparent communication are much lower than the risks of not openly communicating. Among the risks of engaging stakeholders through social media, scholars and practitioners often refer to possible legitimacy crises (Veil et al., 2012). At the same time, social media offer organizations an opportunity to bypass traditional media and offer counter-narratives (Kirby, 2012; Barros, 2014), thereby directly building legitimacy among their stakeholders. Some authors (e.g. Castelló et al., 2016) use the term "networked legitimacy" to refer to the new methods for sustaining an organisation's reputation in the digital age, where companies are openly exposed to conflicting stakeholders' demands on a number of issues. In the new landscape, legitimacy might increase when control decreases. 


\section{ASSUMPTIONS ABOUT NEW MEDIA}

In this stream, new media are seen as tools to be used by the organisation rather than as forces determining strategists' and organisations' strategy work. For instance, Dobusch and Kapeller (2017: 17) write that if the goal is to practice open strategy, "we could see a benefit in developing and marketing tools with a clear focus on either crowds or communities".

New media are portrayed as deliberatively and instrumentally used by organisations and strategists to, for instance, increase market knowledge (Killian and McManus, 2015; Advani and Choudhury, 2001), build fan bases (Shih et al., 2014), co-create products (Arakji and Lang, 2007) and control the corporate reputation (Barros, 2014). In other words, new media are described as something that can be employed and controlled by organisations and strategists. Thus, within this stream, agency is assumed to belong to human beings, who are often depicted as rationally and instrumentally in control. These agents are assumed to determine the role and effects of new media in creating strategic engagement with stakeholders.

\section{INCREASING AND DECREASING CONTROL}

The fourth theme identified in the literature revolves around the consequences of new media usage in employees' daily work. New media may be used to share knowledge, check on private matters, participate in strategy making, disclose information or search for new jobs. In the studies analysed here, the strategic consequences of these behaviours are not consistently portrayed. Some emphasize the possibilities inherent in new ways of working and organizing, while others highlight the potential risks for the organisation. Although this theme has drawn scholarly attention since the early 
2000s, our examination of the relevant corpus seems to point to a shift in the framing of the theme. Concerns about the negative aspects of new media use by employees have increased in recent years, while the positive implications for the changing fabric of the organisation (Zammuto et al., 2007) are now more rarely discussed. Similar to the previous stream, new media are portrayed in this stream of literature as tools to be used in strategy work. In other words, they are believed to be at the organisation's and the strategists' disposal, and human actors determine their role in the organization.

\section{DIAGNOSIS: MAKING WORK VISIBLE}

Although the literature highlights many different consequences, one common diagnosis revolves around how new media transform work by making it visible and the strategic implications of this transformation. Just like consumers can be tracked and made visible through the production and analysis of big data and online communities, scholars stress the possibility of "seeing" what takes place inside the organisation and, hence, managing and organizing it in new ways. Zammuto et al. (2007) emphasize the radical strategic implications of this change for the "fabric" of the organisation. In their conceptual paper, they frame strategy as resulting from the intersection of information technology and organisational features, and they highlight several important changes at this intersection: the possibility of visualizing entire work processes, the ability to manage real-time/flexible product and service innovations, the introduction of virtual collaboration and mass collaboration, and the use of simulation/synthetic reality.

Along similar lines, some authors highlight opportunities for employees to use new media. For example, a number of studies show how new media enhance innovation by making it possible to gather and make visible an increasingly diverse range of 
information, and to communicate with an increasingly diverse group of colleagues (e.g. Gray et al., 2011; Kuegler et al. 2015). Other studies focus on the strategic advantages of organisational transparency for management teams, which are now able to learn how customers are being serviced by employees and to obtain new types of feedback from the market (Bennis 2013).

Some authors warn of the possible drawbacks of making work visible. The main concern expressed in this regard relates to the implications of increased control over employees' work. For instance, studies of employees' strategies for dealing with the visibility and mobility offered by new media point to various dilemmas. Despite the ideology of openness, workers are consciously balancing visibility and invisibility, engagement and disengagement, sharing and control (Gibbs et al. 2013), and public and private boundaries in their social-media presence (McDonald and Thompson 2016), as well as empowerment and enslavement in their voluntary activities (Schlachter et al. 2017). Another dilemma is identified by Healy and Iles (2003), who note that despite the discourse suggesting that new media could help address overly bureaucratic structures, management has increasingly regulated the use of new media through ICT codes of conduct owing to concerns regarding security and efficiency.

\section{DIRECTIONS: BALANCE CONTROL}

The diagnosis that new media make work visible leads to rather ambiguous directions for strategists. Compared to the previous diagnosis, which resulted in relatively consistent pictures of strategists as bringing their rationalities to bear, being occupied with shaping boundaries, building trust and strategically engaging with external stakeholders, the new ways in which work becomes visible in organisations seem to leave strategy scholars somewhat unsure of their strategic implications. 
Scholars agree that the visibility of employees' work might have a significant impact on the employee-employer relationship and, thus, have consequences of strategic importance. However, they do not offer a clear set of recommendations to strategists. On the one hand, researchers emphasize that the new means of surveilling work might lead to enhanced strategic control of resources (Healy and Iles, 2003). The possibility of working outside of regular working hours and work spaces is endorsed as positive (Schlachter et al., 2017). On the other hand, this stream of literature articulates the dilemmas associated with the potential for enhanced control. The ethics of increasing control over employees as a consequence of digitization and datafication are discussed (Hansen and Flyverbom, 2015) as are the potential negative effects for employees (Dutta, 2010; Gibbs et al, 2013; Schlachter et al, 2017). Such discussions lead to calls for corporate responsibility in the wave of digital transformations (Flyverbom et al. 2017).

\section{ASSUMPTIONS ABOUT NEW MEDIA}

This stream of literature offers less homogeneous directions for strategists to follow than the other streams. New media are portrayed as internal organizational tools that can be used by managers and employees to change and control strategy work. Some studies portray and recommend the deliberate use of virtual tools for collaboration and communication by managers and employees (Gray et al., 2011; Kuegler et al., 2015), while others suggest that managers and employees deliberately use or avoid these tools (Gibbs et al., 2013; Schlachter et al., 2017). Despite these differences, this stream of literature describes new media as something organisations and strategists can utilise in their strategy-work. In other words, new media are tools at their disposal, and it is up to them to determine their roles and effects. As in the stream on 
strategic engagement with stakeholders, agency is assumed to belong to organisations and strategists, whose deliberate use of new media can strengthen the traceability, control and transparency of organizational processes.

\section{TRENDS AND GAPS IN THE LITERATURE}

On the basis of our review of an extensive corpus of literature on strategy and new media, we now discuss trends and gaps in this body of scholarly work. After taking stock of the assumptions we teased out from the literature, we propose an alternative route for understanding strategy and new media that challenges existing assumptions (Alvesson and Sandberg, 2014). We end by formulating a future research agenda.

In general, the literature treats technology as a fixed entity and unpacking it is rarely at the centre of the above-reviewed articles. Although all of the articles revolve around new media, our review identified a gap in the literature regarding how new media are configured and how they work. Few articles investigate how new media emerge and are constructed within or outside a given organisation, or the ideas and norms they carry. New media are assumed to be either forces causing change, or tools that are used for strategy work and strategic thinking (see Table 2 for a summary of the analysis).

\begin{tabular}{|l|l|l|l|}
\hline $\begin{array}{l}\text { Streams of } \\
\text { literature }\end{array}$ & Diagnoses & Directions & $\begin{array}{l}\text { Assumptions about new } \\
\text { media }\end{array}$ \\
\hline $\begin{array}{l}\text { A turbulent } \\
\text { environment } \\
\text { for strategy }\end{array}$ & $\begin{array}{l}\text { New grounds for } \\
\text { competitive advantage: }\end{array}$ & $\begin{array}{l}\text { Reinvigorate classical } \\
\text { strategy thinking: }\end{array}$ & $\begin{array}{l}\text { New media are external } \\
\text { forces to which } \\
\text { organisations must adapt }\end{array}$ \\
$\begin{array}{l}\text { Digital data produced in } \\
\text { large amounts are } \\
\text { strategic }\end{array}$ & $\begin{array}{l}\text { Increase control over the } \\
\text { market } \\
\text { Refine segmentation and } \\
\text { make scenario planning } \\
\text { more accurate }\end{array}$ & $\begin{array}{l}\text { Agency resides with new } \\
\text { media - they determine } \\
\text { the organisation's ability } \\
\text { to act and the necessity of } \\
\text { doing so }\end{array}$ \\
\hline
\end{tabular}




\begin{tabular}{|c|c|c|c|}
\hline & $\begin{array}{l}\text { Innovation sustains } \\
\text { competitive advantage }\end{array}$ & Develop new capabilities & \\
\hline $\begin{array}{l}\text { The changing } \\
\text { role of } \\
\text { strategists }\end{array}$ & $\begin{array}{l}\text { Changing } \\
\text { communication: } \\
\text { Management and } \\
\text { employees can } \\
\text { communicate in new } \\
\text { ways } \\
\text { Internal collaboration and } \\
\text { knowledge sharing are } \\
\text { improved }\end{array}$ & $\begin{array}{l}\text { Revisit boundaries and } \\
\text { trust: } \\
\text { Leverage and attend to } \\
\text { internal and external } \\
\text { boundaries } \\
\text { Promote transparency, as it } \\
\text { leads to trust, which leads } \\
\text { to better decision making } \\
\text { and knowledge sharing }\end{array}$ & $\begin{array}{l}\text { New media are internal } \\
\text { forces that bring about } \\
\text { new communication } \\
\text { logics } \\
\text { Agency resides with new } \\
\text { media - they determine } \\
\text { strategists' actions and } \\
\text { choices }\end{array}$ \\
\hline $\begin{array}{l}\text { Strategic } \\
\text { engagement of } \\
\text { stakeholders }\end{array}$ & $\begin{array}{l}\text { Enable community and } \\
\text { participation: } \\
\text { New ways of sending, } \\
\text { receiving and exchanging } \\
\text { information } \\
\text { Interactions with } \\
\text { stakeholders is enhanced } \\
\text { by enabling emotional } \\
\text { engagement } \\
\text { Open innovation, open } \\
\text { strategy making, and co- } \\
\text { creation of products, } \\
\text { services and marketing } \\
\text { content are made possible }\end{array}$ & $\begin{array}{l}\text { Take stakeholder demands } \\
\text { into account: } \\
\text { Create user-centred } \\
\text { business models } \\
\text { Increase the strategic } \\
\text { importance of the } \\
\text { marketing function } \\
\text { Actively work on managing } \\
\text { legitimacy }\end{array}$ & $\begin{array}{l}\text { New media are tools for } \\
\text { establishing new } \\
\text { relationships with } \\
\text { external stakeholders } \\
\text { Agency resides with } \\
\text { strategists - they } \\
\text { determine the strategic } \\
\text { role of new media }\end{array}$ \\
\hline $\begin{array}{l}\text { Increasing } \\
\text { and } \\
\text { decreasing } \\
\text { control }\end{array}$ & $\begin{array}{l}\text { Making work visible: } \\
\text { Possibility to produce } \\
\text { visualizations of internal } \\
\text { work processes } \\
\text { More diverse and direct } \\
\text { information from outside } \\
\text { the organization } \\
\text { Blurring of boundaries: } \\
\text { public/private, work/non- } \\
\text { work, autonomy/control }\end{array}$ & $\begin{array}{l}\text { Balance control: } \\
\text { Enhance strategic control } \\
\text { by surveilling and } \\
\text { leveraging new information } \\
\text { sources } \\
\text { Attend to ethical concerns } \\
\text { arising from increased } \\
\text { control }\end{array}$ & $\begin{array}{l}\text { New media are tools to } \\
\text { control employees } \\
\text { Agency resides with } \\
\text { managers - they } \\
\text { determine the ends for } \\
\text { which new media are } \\
\text { used }\end{array}$ \\
\hline
\end{tabular}

Table 2: Summary of the analysis

The fact that new media are generally treated as fixed entities that either shape the strategy of organisations or can be used strategically by organisations implies that the focus is rarely on new media companies and their influence on other companies' strategy making. Facebook, Twitter and other new media infrastructures are treated as 
relatively neutral tools rather than as corporations that produce certain artefacts in certain ways with particular logics and ideologies.

The trend of "blackboxing" new media and describing them as 'forces' or 'tools' is related to assumptions about where the agency resides. When new media are portrayed as forces in the environment, they are assumed to have agency and to determine the conditions for strategy. When new media are portrayed as tools, agency is assigned to humans. Strategists are sometimes portrayed as super-rational, powerful actors who need to make decisions about technologies. At other times, they are described as open, democratic facilitators of internal dialogues on new media platforms. Sometimes they are viewed as agitators in online communities and crowds. Our analysis points to an important gap in the literature with regards to agency: very few articles operate with a view of agency as distributed between humans and technologies.

In the following, we discuss this gap in light of alternative understandings of the role of technology in organisations as well as the relationship between human and material agency. We discuss how these theoretical resources offer concepts that can be cultivated to develop a new understanding, inspire new types of analytical questions, and shape new methodological sensitivities regarding strategy and new media.

The review indicated that few researchers argued for and analysed the intertwined roles of new media technologies and human strategists. In fact, only 5 of the 130 articles we reviewed adopted this approach. Notably, the symmetrical approach to humans and technology is a growing tenet in organisation studies as well as in 
information systems, where it is informed by research in science, technology and sociomateriality (see, e.g., Czarniawska and Hernes 2005; Leonardi and Vaast 2017; Orlikowski 2007; Mazmanian et al. 2014). Most strategy research concurs that strategy should be considered neither a purely social phenomenon nor a merely cognitive exercise, but as a practice that is thoroughly entangled with materiality (see, e.g., Jarzabkowski 2005; Jarzabkowski and Spee 2009; Johnson et al. 2007; Whittington 2006; Balogun et al., 2014; Whittington, 2014). However, the assumptions underlying much of the strategy and new media literature seem to entail that theoretical and methodological priority be given to investigating humans as either agentic strategisers who are free from any considerations of constraints and affordances of technologies, or as determined by new media with very little room for choice. Whittington (2014: 89) points out that it is high time for strategy research "to catch up with the role of materiality and technology in strategizing", especially in relation to new media, big data, new analytical tools and social media.

In challenging the non-articulated assumptions underlying the literature reviewed in this paper, we propose an alternative theoretical route to understanding strategy and new media: 1) relying on a relational view of agency, 2) using the analytical concept of affordances, and 3) adopting an agnostic and symmetrical methodology for tracing strategy-making assemblages. Although we build on and resonate with insights and the active debate in organisation studies and information systems (see, e.g., the review on social media and their affordances for organizing by Leonardi and Vaast, 2017), our review is distinct in at least three respects. First, it specifically focuses on what it means to adopt a relational view of agency in attempts to understand new media and strategy. As such, it takes current debates in the strategy community into account. 
Second, it proposes not only to rely on the analytical concept of affordances as a way to substantiate a relational view of agency but also to empirically trace strategymaking assemblages. Third, it aims to explain the methodological implications and, perhaps, the necessities of this alternative perspective. In the following, therefore, we discuss aspects of the ontological roots, analytical tools and methodology of a relational approach, and we sketch out its potential contributions to our understanding of strategy and new media relative to our analysis of the literature.

\section{A RELATIONAL PERSPECTIVE ON AGENCY}

In scholarship grounded in a relational ontology, agency does not rest with the individual but is the result of relations (Emirbayer 1997). In other words, it is constituted in and through sociomaterial relations (Pollock 2012, a relational materiality (Law, 2004), actor networks (Latour, 2005) or a mangle of practice (Pickering et al., 1995). A relational view of agency informs some studies of strategy (e.g. Kaplan 2011) but is more common in organization studies and information systems studies (e.g. Orlikowski 2007; Scott and Orlikowski 2012). Such studies often have a constructivist orientation in the sense that "'the capacity to act' $[\ldots]$ is discovered when studying how worlds become constructed in a certain way" (Cooren 2006, p. 11, cited in Orlikowski 2007, p. 1438).

In our review, we identified a few articles adopting a relational view on agency (e.g. Zammuto et al. 2007; Kwayu et al. 2017; Neeley and Leonardi 2018). These do not favour human agency but cultivate an analytical sensibility to other agencies. This allows them to highlight the active role played by both new media and humans in strategy making, and to portray actions as resulting from interactions between them. Whittington's (2015) idea of the 'massification of strategy' offers two examples of 
how material agency can be highlighted in discussions of new media and strategy. First, he points out that strategy work is often based on mass-produced material artefacts, such as hardware and software, which align certain strategy practices across organisational sites. Second, he discussed the increasing use of social-media platforms as tools for mass participation in strategy work, which extends beyond strategists' elites.

If we look beyond the articles included in the review, we find more inspiration for advancing a relational perspective on agency in future research on strategy and new media (e.g. Ghose and Ipeirotis 2014; Makkonen and Virtanen 2015; Kaplan 2011; Plesner and Gulbrandsen 2015). Kaplan's (2011) article on the use of PowerPoint presentations in strategy making is a fine example of the contributions a relational view on agency can make. She explicitly adopts a perspective on technology that neither views the PowerPoint technology as determining everything strategists do nor assumes that strategists are completely in control of the way the PowerPoint software influences their work. This allows Kaplan to analyse PowerPoints as a genre able to mobilize conversation and knowledge production in specific ways. As such, it is both shaping and being shaped by strategy.

\section{AN ANALYTICAL CONCEPT: AFFORDANCES}

If we want to study strategy and new media with an understanding of agency as a phenomenon established in relations between humans and technology, we need concepts that help us theorise and more closely investigate how new media act in relation to strategists and others. We therefore propose using the concept of 'affordances', which comes from Gibson's (1986) ecological psychology and is 
defined as a possible action that is available in the environment (McGrenere and Ho, 2000). This means that objects, like technologies, have some features that allow them to be used in different ways, but their use depends on how these features are perceived by the user. In the case of new media, this implies that their affordances, when intertwined with other objects, spaces and humans, frame but do not determine "the possibility of agentic action" (Hutchby 2001, p. 444) - strategic action in our case.

This concept introduces a foundation for exploring new media that differs from the assumptions informing most of the reviewed articles. With an affordance approach, new media cannot be assumed to always result in, for instance, a new logic of value creation and managerial work, because they possess some intrinsic properties. Similarly, they do not necessarily force all strategists to adapt and they cannot be understood as merely tools at the mercy of strategists. Instead, new media affordances should be viewed as situational and emerging in relation to particular (human and non-human) actors (see, e.g., Vaast et al. 2017; Leonardi and Vaast 2017). Although not explicitly concerned with strategy, Scott and Orlikowski's (2012) analysis of rankings on social-media sites (i.e. TripAdvisor's popularity index) shows how new media allow for increased visibility of rankings and how this becomes integral to hotels' strategic practices as they move up and arrankings. This approach to technology allows us to capture the dynamic relationships among technological features, technology use and managerial/strategic action. As such, the conditions for strategy can be theorized and studied as "thoroughly dependent upon databases and algorithms that are continually updated and management practices in contexts that are highly dynamic" (Scott and Orlikowski 2012, p. 39). 


\section{ASSEMBLAGE}

We argue for an approach to new media and strategy based on a relational view of agency and an ambition to open up technologies by considering their affordances. This has implications for methodology. A methodology based on such ambitions needs to have an agnostic, symmetrical view of which actors should be studied, and precisely how they make a difference for and with each other in practice (Latour 2005). Assumptions about the existence of an inside and an outside of an organization, or a distinct social and a distinct material domain are challenged by such a view. We suggest that the concept of assemblage can be useful as a foundation for an alternative methodological approach to strategy and new media.

The term 'assemblage' originates from the actor-network tradition and captures "a combination of heterogeneous elements that have been carefully adjusted to one another" (Callon 2007, p. 319). It implies that we pay attention to all sorts of elements in a strategy process, and that we exploratively and qualitatively follow how they are interlinked and make a difference for one another. The tracing of assemblages implies that neither humans nor technologies are seen as the starting point of strategic action, but the researcher needs to be sensitive to which elements make a difference in an assemblage and how this happens. The agency in strategy processes is distributed and not solely in the hands of human strategists, and new media may have different functions. The use of assemblages as a basis for a research design implies an empiricist, inductive approach that helps surpass á priori entities and categories. 
'Assemblage' has several near-synonyms, such as 'actor networks', 'configurations' and 'action nets' (Czarniawska, 2004). They all serve the same purpose - to question where agency resides and how actors are connected. Mazmanian et al. (2014) propose the process of "dynamic reconfiguration" to capture the ongoing and changing work involved in delimiting and defining the relationship between the social and the material - not as separate entities that are brought together but rather their configuration in relation to each other.

To sum up how relational agency, affordances and assemblages relate to one another, we propose investigating agency in strategy and new media from a relational perspective. To do so, researchers can examine new media affordances made available within a strategy-making assemblage that can be diligently and carefully traced across organisations, in space and over time. Affordances not only emerge in an assemblage but are also realized by it. Affordances and agency are connected by the fact that affordances facilitate and enable certain actions (Withagen et al. 2012). For our understanding of strategy and new media, this implies that strategy emerges when different configurations of actors (strategists, new media or other actors) create different possibilities for strategic action.

\section{A WAY FORWARD}

This theoretical discussion has implications for future research in strategy and new media. The combination of a relational view of agency, an interest in opening up technology, and an agnostic, symmetrical methodological approach establishes a foundation for studying strategy and new media in a way that can begin to compensate for the gaps in the literature identified in this review. This new route can shape a future research agenda on strategy and new media. With inspiration from 
Gulbrandsen and Just (2016), we offer suggestions for relevant analytical questions and methods in Table 3.

\begin{tabular}{|l|l|l|}
\hline Theoretical concept & Analytical question & Relevant methods \\
\hline Agency & $\begin{array}{l}\text { Who and what makes a } \\
\text { difference in practice (that is } \\
\text { considered strategic)? }\end{array}$ & $\begin{array}{l}\text { Shadowing of people and } \\
\text { objects, ethnographic } \\
\text { observations, trace } \\
\text { observations, software } \\
\text { scripts and scraping, actor- } \\
\text { network analyses }\end{array}$ \\
& $\begin{array}{l}\text { What are new media's } \\
\text { properties and how are their } \\
\text { possibilities for action } \\
\text { perceived? }\end{array}$ & $\begin{array}{l}\text { Interviews, document } \\
\text { analyses, ethnographic } \\
\text { observations, software } \\
\text { walk-throughs, } \\
\text { experiments }\end{array}$ \\
& $\begin{array}{l}\text { Which social and } \\
\text { technological elements } \\
\text { become interlinked in } \\
\text { strategy? }\end{array}$ & $\begin{array}{l}\text { Actor-network-analyses, } \\
\text { crawling, tag clouds, } \\
\text { agent-based modelling, } \\
\text { network analysis agent- } \\
\text { based modelling, archival } \\
\text { analysis of new media }\end{array}$ \\
\hline Assemblage & & ance
\end{tabular}

Table 3: Theoretical concepts, research foci and relevant methods

To demonstrate how this research agenda can contribute to our understanding of strategy and new media, we will briefly discuss how the four dominant themes covered above would be viewed differently, and how our understanding of those themes could be enriched by a relational view of agency, an analytical sensitivity to affordances and a methodological appreciation of assemblages. 
In relation to the first stream - the turbulent environment for strategy - the proposed approach is better able to explain, for example, how changes are not simply driven by new media but by how certain new media technologies together with certain human actors produce specific possibilities of action, some of which some are realized. Therefore, the turbulent environment is the result of the possibilities for action (both social and technological) that the elements in the assemblage utilize. The proposed approach allows us to explore questions like: Why do differences exist between different markets even though they have access to similar new media technologies? Why do organisations in the same market act differently even though they use the same technologies? Why do analogous strategic actions implemented by different organisations in the same market have different outcomes?

In connection to the second stream, the proposed approach would offer a better understanding of how strategists actively participate in creating new roles for themselves. From a relational agency perspective, the changing role of strategists is the result of the fact that strategy-making assemblages of humans and non-humans realize certain possibilities for action. These possibilities are not determined by available technologies but constructed in the relation between new media (with their capabilities) and the involved strategists. Research based on the perspective presented here would focus on how certain strategists utilize certain opportunities, while they are blind to or ignore others. As such, it can move beyond the descriptive and apolitical level to explore the agendas of the involved agents, tracing connections among technologies, people and organizations over time and space. For example, it would be important to trace how technologies travel around the world as well as over time, and how given technologies enter given organization and certain strategic 
activities, whether they are internally developed or acquired from, for instance, an external IT firm or open source. Key questions in this regard include: Why are specific affordances available in this situation? How does the combination of the specific architecture of a new media platform and the abilities of a specific strategist produce a certain outcome? What norms and interests are inscribed into and carried by technologies? How are these inscriptions made within or outside a specific organization?

An analysis based on different assumptions about agency and technology would also reveal a more nuanced understanding of strategic engagement with stakeholders. Consider, for example, social media - a topic with which several scholars within this theme are preoccupied. The engagement that a platform like Facebook affords is not the design of a strategist alone. Rather, it depends on the specific assemblage of elements that are involved in the organisation's presence on social media. First, the platform itself has certain properties that afford and constrain the possibilities of action for the strategist. These affordances and constraints are the result of Facebook's business model, which privilege certain activities that benefit Facebook rather than the strategist. Second, Facebook affords and limits stakeholders' engagement independent of the strategist and in accordance with its own business model. Hence, in order to fully understand an organisation's strategy in relation to social media, the analysis must take into account the assemblage that makes certain possibilities for action available. It must then investigate the possibilities that are actually realized and why, instead of assuming that the actions taken are the result of a sole strategist's ideas. This would allow the analysis to move beyond the descriptive and prescriptive to address pertinent questions, such as: How do algorithms influence 
the strategic choices available to strategists? How do social-media platforms' business models afford particular strategic actions for organisations?

Finally, in relation to the fourth stream on increased and decreased control, the proposed perspective offers another understanding of how certain new media, irrespective of the strategist's intentions, have certain affordances that, for instance, make control and surveillance possible without the active engagement of the strategist. An analysis focused on tracing assemblages, affordances and agencies would show that even though the manager or strategist can make decisions about how to use a particular platform, those decisions are afforded and constrained not just by the new media technologies but also by other elements present in the assemblage. For instance, an important element in any assemblage related to new media is the European Union's General Data Protection Regulation. This element is particularly interesting because it affects the possibilities of action available not only to managers but also to the new media platforms. Hence, an analysis focused on relational agency and assemblages could shed light on questions like: How are regulations interpreted by organisations as well as technology providers? How does the technology provider's interpretation affect technological affordances? What other actors have agency in relation to this platform?

\section{CONCLUSIONS}

The possibilities and threats posed by new media have been a matter of concern in the strategy literature for a number of years. In a review of the literature, we identified different ways of conceptualizing the role of new media in strategy: as disruptive forces in an increasingly turbulent environment, as internal forces changing the role of strategists, as tools for engaging stakeholders in strategy, and as mechanisms for 
increasing and decreasing the control necessary for strategy making. Our analysis highlighted the diagnoses that strategy scholars provide of new conditions for strategy work and the directions they suggest that strategists should take on the basis of those diagnoses. We then investigated and challenged the assumptions underlying the diagnoses and directions put forward in the literature, especially in relation to agency. We observed a tendency to portray strategy as made by humans whose actions either are determined by new media or determine their development. We discussed and challenged these assumptions on the basis of a relational view of agency and an ambition to 'open up' new media. We suggested that even if a few scholars pursue similar projects, this approach should inform a new research agenda on strategy and new media based on a relational view of agency, an analytical exploration of affordances of new media and a methodological sensitivity to strategy-making assemblages. 


\section{REFERENCES}

Abell, D. F. (1980), Defining the Business: The Starting Point of Strategic Planning; Englewood Cliffs, NJ: Prentice-Hall

Abernathy, W. J. (1978) The Productivity Dilemma: Roadblock to Innovation in the Automobile Industry; Baltimore, MD: Johns Hopkins University Press.

Advani, R., and Choudhury, K. (2001). Making the Most of B2C Wireless. Business Strategy Review, 12(2), 39-49.

Akman, I., and Mishra, A. (2017). Factors influencing consumer intention in social commerce adoption. Information Technology \& People, 30(2), 356-370.

Alvesson, M. and Sandberg, J. (2014). Habitat and Habitus: Boxed-in versus BoxBreaking Research. Organization Studies 35(7), 967-987

Andersen, T. J., and Foss, N. J. (2005). Strategic opportunity and economic performance in multinational enterprises: The role and effects of information and communication technology. Journal of International Management, 11(2 SPEC. ISS.), 293-310.

Anderson, P.M. and Tushman, A. (1990) Technological discontinuities and dominant designs: A cyclical model of technological change. Administrative Science Quarterly, 35 (4), 604-633

Antoniou, P. H., and Ansoff, H. I. (2004). Strategic Management of Technology.

Technology Analysis \& Strategic Management, 16(2), 275-291.

Arakji, R., and Lang, K. (2007). Digital Consumer Networks and Producer-Consumer Collaboration: Innovation and Product Development in the Video Game Industry. Journal of Management Information Systems, 24(2), 195-219.

Archer-Brown, C., and Kietzmann, J. (2018). Strategic knowledge management and enterprise social media. Journal of Knowledge Management, JKM-08-2017-0359. Armano, D. (2010). Fire Your Marketing Manager and Hire a Community Manager. Harvard Business Review, 88(10), 24.

Balogun, J., Jacobs, C., Jarzabkowski, P., Mantere, S., and Vaara, E. (2014). Placing strategy discourse in context: Sociomateriality, sensemaking, and power. Journal of Management Studies, 51(2), 175-201.

Baptista, J., Wilson, A. D., Galliers, R. D., and Bynghall, S. (2017). Social Media and the Emergence of Reflexiveness as a New Capability for Open Strategy. Long Range Planning, 50(3), 322-336.

Barley, S. R. (1986) Technology as an Occasion for Structuring: Evidence from Observations of CT Scanners and the Social Order of Radiology Departments. Administrative Science Quarterly, 31 (1): 78-108

Barley, S. R. (1998). What can we learn from the history of technology? Journal of Engineering and Technology Management 15, 237-255.

Barros, M. (2014). Tools of Legitimacy: The Case of the Petrobras Corporate Blog. Organization Studies, 35(8), 1211-1230.

Bennis, W. (2013). Leadership in a Digital World: Embracing Transparency and Adaptive Capacity. MIS Quarterly, 37(2), 635-636.

Birkinshaw, J., and Caulkin, S. (2012). How should managers spend their time?:

Finding more time for real management. Business Strategy Review, 23(4), 62-65.

Buhalis, D. (2004). eAirlines: strategic and tactical use of ICTs in the airline industry. Information \& Management, 41(7), 805-825.

Callon, M. (2007). What Does It Mean to Say that Economics is Performative? In D. MacKenzie, F. Muniesa and L. Siu (eds.), Do Economists Make Markets? On the Performativity of Economics. Princeton: Princeton University Press: 311-357. 
Castelló, I., Etter, M., and Årup Nielsen, F. (2016). Strategies of Legitimacy Through Social Media: The Networked Strategy. Journal of Management Studies, 53(3), 402432.

Cooper, A. C. and Schendel, D. (1976) Strategic responses to technological threats. Business Horizons, 19 (1), 61-69

Crane, A., and Glozer, S. (2016). Researching Corporate Social Responsibility Communication: Themes, Opportunities and Challenges. Journal of Management Studies, 53(7), 1223-1252.

Czarniawska, B. (2004). On time, space, and action nets. Organization, 11(6), 773791.

Czarniawska, B. and Hernes, T. (2005) Actor-Network Theory and Organizing. Copenhagen: CBS Press.

Dameron, S., Lê, J. K., and LeBaron, C. (2015). Materializing Strategy and

Strategizing Materials: Why Matter Matters. British Journal of Management, 26, S1S12.

David, R. J., and Han, S. K. (2004). A systematic assessment of the empirical support for transaction cost economics. Strategic Management Journal, 25(1), 39-58.

Day, G. S., and Schoemaker, P. J. H. (2016). Adapting to Fast-Changing Markets and Technologies. California Management Review, 58(4), 59-77.

Dobusch, L., and Kapeller, J. (2017). Open strategy-making with crowds and communities: Comparing Wikimedia and Creative Commons. Long Range Planning (in press) 1-19.

Dong, J. Q., and Wu, W. (2015). Business value of social media technologies:

Evidence from online user innovation communities. Journal of Strategic Information Systems, 24(2), 113-127.

Dongback, S. (2017). Digital Business Convergence and Emerging Contested Fields:

A Conceptual Framework. Journal of the Association for Information Systems, 18(10), 687-702.

Dutta, S. (2010). What's your Personal Social Strategy. Harvard Business Review, (November).

El Sawy, O. A., Malhotra, A., Park, Y. K., and Pavlou, P. A. (2010). Seeking the configurations of digital ecodynamics: It takes three to tango. Information Systems Research, 21(4), 835-848.

Emirbayer, M. (1997). Manifesto for a Relational Sociology. American Journal of Sociology, 103(2): 281-317.

Esteves, J. (2008). Where is your blog? Business Strategy Review, 19(4), 62-70. Flyverbom, M., Deibert, R., and Matten, D. (2017). The Governance of Digital Technology, Big Data, and the Internet: New Roles and Responsibilities for Business. Business \& Society

Foster, R. N. (1985) Timing technological transitions. Technology in Society, 7 (2-3), 127-141

Gagliardi, D. (2013). Next generation entrepreneur: Innovation strategy through Web 2.0 technologies in SMEs. Technology Analysis and Strategic Management, 25(8), 891-904.

Gandia, R., and Parmentier, G. (2017). Optimizing value creation and value capture with a digital multi-sided business model. Strategic Change, 26(4), 323-331.

García-Moya, L., Kudama, S., Aramburu, M. J., and Berlanga, R. (2013). Storing and analysing voice of the market data in the corporate data warehouse. Information Systems Frontiers, 15(3), 331-349.

Gençer, M., and Oba, B. (2011). Organising the digital commons: A case study on 
engagement strategies in open source. Technology Analysis and Strategic

Management, 23(9), 969-982.

Ghose, A., Ipeirotis, P. G., and Li, B. (2014). Examining the Impact of Ranking on

Consumer Behavior and Search Engine Revenue. Management Science, 60(7), 16321654.

Gibbs, J. L., Rozaidi, N. A., and Eisenberg, J. (2013). Overcoming the "Ideology of Openness": Probing the affordances of social media for organizational knowledge sharing. Journal of Computer-Mediated Communication, 19(1), 102-120.

Gibson, J.J. (1986). The Ecological Approach to Visual Perception. Mahwah, NJ: Lawrence Erlbaum Associates.

Glassey, O. (2009). Exploring the weak signals of starts-ups as a folksonomic system. Technology Analysis and Strategic Management, 21(3), 321-332.

Granados, N., and Gupta, A. (2013). Transparency Strategy: Competing with Information in a Digital World. MIS Quarterly, 37(2), 637-642.

Gray, P. H., Parise, S., and Iyer, B. (2011). Innovation Impacts of Using Social Bookmarking Systems. Mis Quarterly, 35(3), 629-643.

Greenstein S, Lerner J and Stern S. (2013) Digitization, innovation, and copyright: What is the agenda? Strategic Organization.

Grover, V., and Kohli, R. (2013). Revealing Your Hand: Caveats in Implementing Digital Business Strategy. MIS Quarterly, 37(2), 655-663.

Guinan, P. J., Parise, S., and Rollag, K. (2014). Jumpstarting the use of social technologies in your organization. Business Horizons, 57(3), 337-347.

Gulbrandsen, I. T., and Just, S. N. (2011). The collaborative paradigm: towards an invitational and participatory concept of online communication. Media, Culture \& Society, 33(7), 1095-1108.

Gulbrandsen, I., and Just, S. (2016). In the Wake of New Media: Connecting the Who with the How of Strategizing Communication. International Journal of Strategic Communication, 10(4), 223-237.

Haefliger, S., Monteiro, E., Foray, D., and von Krogh, G. (2011). Social software and strategy. Long Range Planning, 44(5-6), 297-316.

Hanna, R., Rohm, A., and Crittenden, V. L. (2011). We're all connected: The power of the social media ecosystem. Business Horizons, 54(3), 265-273.

Hansen, H. K., and Flyverbom, M. (2015). The politics of transparency and the calibration of knowledge in the digital age. Organization, 22(6), 872-889.

Healy, M., and Iles, J. (2003). The impact of information and communications technology on managerial practices: the use of codes of conduct. Strategic Change, 12(4), 185-193.

Hienerth, C., Keinz, P., and Lettl, C. (2011). Exploring the nature and implementation process of user-centric business models. Long Range Planning, 44(5-6), 344-374.

Huang, J., Baptista, J., and Galliers, R. D. (2013). Reconceptualizing rhetorical practices in organizations: The impact of social media on internal communications. Information and Management, 50(2-3), 112-124.

Huang, J., Baptista, J., and Newell, S. (2015). Communicational ambidexterity as a new capability to manage social media communication within organizations. Journal of Strategic Information Systems, 24(2), 49-64.

Hutchby, I. (2001). Technology, Texts, and Affordances. Sociology, 35(2): 441-456 Jarzabkowski, P. (2005). Strategy as practice; an activity based approach. London, UK: Sage.

Johnson, G., Langley, A., Melin L. and Whittington, R. (2007). Strategy as Practice: Research Directions and Resources. Cambridge, UK: Cambridge University Press. 
Kalakota, R., and Konsynski, B. (2000). The Rise of Neo-Intermediation: The Transformation of the Brokerage Industry. Information Systems Frontiers, 2(1), 115128.

Kallinikos, J., and Constantiou, I. D. (2015). Big data revisited: A rejoinder. Journal of Information Technology, 30(1), 70-74.

Kaplan, S. (2011) 'Strategy and PowerPoint: An Inquiry into the Epistemic Culture and Machinery of Strategy Making'. Organization Science, 22(2): 320-346.

Killian, G., and McManus, K. (2015). A marketing communications approach for the digital era: Managerial guidelines for social media integration. Business Horizons, 58(5), 539-549.

Kim, E., Nam, D. Il, and Stimpert, J. L. (2004). The applicability of Porter's generic strategies in the digital age: Assumptions, conjectures, and suggestions. Journal of Management, 30(5), 569-589.

Kirby, J. (2012). Trust in the Age of Transparency: Interaction. Harvard Business Review.

Koushik, S., Birkinshaw, J., and Crainer, S. (2009). Using Web 2.0 to create Management 2.0. Business Strategy Review, 20(2), 20-23.

Kuegler, M., Smolnik, S., and Kane, G. (2015). What's in IT for employees? Understanding the relationship between use and performance in enterprise social software. Journal of Strategic Information Systems, 24(2), 90-112.

Kwayu, S., Lal, B., and Abubakre, M. (2017, December 20). Enhancing

Organisational Competitiveness Via Social Media - a Strategy as Practice Perspective. Information Systems Frontiers, pp. 1-18.

Lang, K., Shang, R., and Vragov, R. (2015). Consumer Co - creation of Digital Culture Products: Business Threat or New Opportunity? Journal of the Association for Information Systems ·, 16(9), 766-798.

Lanzolla, G., and Anderson, J. (2008). Digital transformation. Business Strategy Review, 19(2), 72-76.

Latour, B. (2005). Reassembling the Social - An Introduction to Actor-NetworkTheory. Oxford: Oxford University Press.

Lau, R. Y. K., Liao, S. S. Y., Wong, K. F., and Chiu, D. K. W. (2012). Web 2.0 Environmental scanning and adaptive decision support for business mergers and acquisitions. MIS Quarterly: Management Information Systems, 36(4), 1239-1268. Law, J. (2004). After method: Mess in social science research. Routledge.

Leonardi, P. M., and Bailey, D. E. (2008). Transformational technologies and the creation of New Work practices: Making implicit knowledge explicit in task-based offshoring. MIS Quarterly, 32(2).

Leonardi, P. M. (2013). Theoretical foundations for the study of sociomateriality. Information and organization, 23(2), 59-76.

Leonardi, P.M. and Vaast, E. (2017) Social media and their affordances for organizing: a review and agenda for research. Academy of Management Annals, 11(1).

Lettice, F., and Brayshaw, K. (2007). Using graphical techniques to communicate strategy: an exploratory study. Strategic Change, 16(4), 145-159.

Lovejoy, K., and Saxton, G. D. (2012). Information, Community, and Action: How Nonprofit Organizations Use Social Media. Journal of Computer-Mediated Communication, 17(3), 337-353.

Luo, J., Pan, X., and Zhu, X. (2015). Identifying digital traces for business marketing through topic probabilistic model. Technology Analysis and Strategic Management, 27(10), 1176-1192. 
Makkonen, H., and Virtanen, K. (2015). Social capital approach on Enterprise 2.0: a multiple case study. Technology Analysis and Strategic Management, 27(10), 12121225.

Maidique, A. M. and Patch, P. (1988) Corporate strategy and technological policy. In Tushman, M. L. and Moore, W. L (eds.) Readings in the Management of Innovation, Cambridge, MA, USA: Ballinger (2nd edition)

Manovich, L. (2001) The Language of New Media. Cambridge, MA: MIT Press.

Mazmanian, Melissa, Marisa Cohn, and Paul Dourish. "Dynamic Reconfiguration in Planetary Exploration: A Sociomaterial Ethnography." MIS Quarterly 38, no. 3 (September 2014): 831-848.

McAfee, A. and Brynjofsson, E. (2008). Investing in the IT that makes a competitive difference. Harvard Business Review.

McDonald, P., and Thompson, P. (2016). Social Media(tion) and the Reshaping of Public/Private Boundaries in Employment Relations. International Journal of Management Reviews, 18(1), 69-84.

McGrenere, J. and Ho, W. (2000). Affordances: Clarifying and Evolving a Concept. Proceedings of Graphics Interface 2000 Conference, 15-17 May, Montreal: 179-186. Miah, S. J., Vu, H. Q., Gammack, J., and McGrath, M. (2017). A Big Data Analytics Method for Tourist Behaviour Analysis. Information and Management, 54(6), 771785.

Mol, J. M., Wijnberg, N. M., and Carroll, C. (2005). Value chain envy: Explaining new entry and vertical integration in popular music. Journal of Management Studies. Molteni, L., and Ordanini, A. (2003). Consumption patterns, digital technology and music downloading. Long Range Planning, 36(4), 389-406.

Neeley, T. B., and Leonardi, P. M. (2018). Enacting knowledge strategy through social media: Passable trust and the paradox of nonwork interactions. Strategic Management Journal, 39(3), 922-946.

Newbert, S. L. (2007). Empirical research on the resource-based view of the firm: An assessment and suggestions for future research. Strategic Management Journal, 28(2), 121-146.

Nylén, D., and Holmström, J. (2015). Digital innovation strategy: A framework for diagnosing and improving digital product and service innovation. Business Horizons, 58(1), 57-67.

Oliver, J. J., and Parrett, E. (2018). Managing future uncertainty: Reevaluating the role of scenario planning. Business Horizons, 61(2), 339-352.

Orlikowski, W. J. (1992). The Duality of Technology - Rethinking the Concept of Technology in Organizations. Organization Science, 3(3), 398-427.

Orlikowski, W.J. (2007) Sociomaterial Practices: Exploring Technology at Work. Organization Studies, 28(09): 1435-1448.

Orlikowski, W. J., and Scott, S. V. (2008). Sociomateriality: Challenging the Separation of Technology, Work and Organization. The Academy of Management Annals, 2(1).

Pagani, M. (2013). Digital Business Strategy and Value Creation: Framing the Dynamic Cycle of Control Points. MIS Quarterly, 37(2), 617-632.

Paroutis, S., and Al Saleh, A. (2009). Determinants of knowledge sharing using Web 2.0 technologies. Journal of Knowledge Management, 13(4), 52-63.

Pickering, A., and Papineau, D. (1995). The mangle of practice: Time, agency and science. Nature, 377(6549), 491-491.

Plesner, U., and Gulbrandsen, I. T. (2015). Strategy and New Media: A research agenda. Strategic Organization, 13(2), 153-162. 
Pollock, N. (2012). Ranking Devices: The Socio-Materiality of Ranking. In P. M. Leonardi, B. A. Nardi and J. Kallinikos (eds.), Materiality and Organizing. Social Interaction in a Technological World. Oxford: Oxford University Press: 91-112. Porter, M. E. (1983) The technological dimension of competitive strategy in Rosenbloom, R. S. (ed.) Research on Technological Innovation, Management and Policy, Greenwich, CT: JAI Press

Quinton, S., and Harridge-March, S. (2006). The interaction of technology in entrepreneurial marketing: an illustrative case from a wine merchant. Strategic Change, 15(2), 85-102.

Rosenberger, L., Nash, J., and Graham, A. (2009). Blazing the new digital trail. Business Strategy Review, 20(1), 89-94.

Sasaki, H. (2011). A computing theory for collaborative and transparent decision making under time constraint. In Information Systems Frontiers (Vol. 13, pp. 207220).

Schlachter, S., Mcdowall, A., Cropley, M., and Inceoglu, I. (2017, November 3). Voluntary Work-related Technology Use during Non-work Time: A Narrative Synthesis of Empirical Research and Research Agenda. International Journal of Management Reviews.

Schwartz, J. (2005). if you want to lead, blog. Harvard Business Review, 83(11), 30.

Scott, S. V., and Orlikowski, W. J. (2012). Reconfiguring relations of accountability: Materialization of social media in the travel sector. Accounting, organizations and society, 37(1), 26-40.

Segars, A. H., and Kohut, G. F. (2001). Strategic communication through the world wide web: an empirical model of effectiveness in the CEO's letter to shareholders. Journal of Management Studies, 38(4), 535-556.

Setia, P., Venkatesh, V., and Joglekar, S. (2013). Leveraging Digital Technologies: How Information Quality Leads to Localized Capabilities and Customer Service Performance. MIS Quarterly, 37(2), 565-590.

Shih, C. C., Lin, T. M. Y., and Luarn, P. (2014). Fan-centric social media: The Xiaomi phenomenon in China. Business Horizons, 57(3), 349-358.

Singer, J. (2006). Systems marketing for the information age. MIT Sloan Management Review, 48(1), 96.

Spee, A. P., and Jarzabkowski, P. (2009). Strategy tools as boundary objects.

Strategic Organization, 7(2), 223-232.

Spenner, P. (2010). Why you need a new-media "ringmaster." Harvard Business Review, 88(12).

Stace, D., Courtney, N., and Holtham, C. (2005). Stepping ahead with technology: but not too far! Strategic Change, 14(4), 179-193.

Stace, D., Holtham, C., and Courtney, N. (2004). Mapping opportunity space: options for a sustainable e-strategy. Strategic Change, 13(5), 237-251.

Straker, K., and Wrigley, C. (2016). Designing an emotional strategy: Strengthening digital channel engagements. Business Horizons, 59(3), 339-346.

Täuscher, K. (2017). Leveraging collective intelligence: How to design and manage crowd-based business models. Business Horizons, 60(2), 237-245.

Thompson, J.D. and Bates, F.L. (1957) Technology, organization, and administration. Administrative Science Quarterly, 2(3): 235-343.

Thompson, J. D. (1967) Organization in Action: Social Science Bases of Administrative Theory, New York: McGraw-Hill. 
Trantopoulos, K., von Krogh, G., Wallin, M. W., and Woerter, M. (2017). External knowledge and information technology: Implications for process innovation performance. MIS quarterly, 41(1), 287-300.

Tsekouras, G., Kanellou, D., and Rai, N. (2013, March). Redefining learning networks through ICT capabilities: Representations, behaviours and intermediation strategies. Technology Analysis and Strategic Management.

Tushman, M. L. and Anderson, P. (1986) Technological discontinuities and organizational environments. Administrative Science Quarterly, 31 (3), 439-465.

Vaast, E., Safadi, H., Lapointe, L., and Negoita, B. (2017). Social media affordances for connective action: an examination of microblogging use during the Gulf of Mexico oil spill. Mis quarterly, 41(4), 1179-1206.

Wales, W. J., Gupta, V. K., and Mousa, F.-T. (2011). Empirical research on entrepreneurial orientation: An assessment and suggestions for future research. International Small Business Journal, 3(4), 357-383.

Vallaster, C., and von Wallpach, S. (2013). An online discursive inquiry into the social dynamics of multi-stakeholder brand meaning co-creation. Journal of Business Research, 66(9), 1505-1515.

van Wegberg, M., van Witteloostuijn, A., and Joel, A. C. B. and H. R. G. (2001). Strategic management in the new economy: Modern information technologies and multichannel contact strategies. In Advances in Strategic Management (Vol. Volume 18, pp. 263-304).

Veil, S. R., Sellnow, T. L., and Petrun, E. L. (2012). Hoaxes and the Paradoxical Challenges of Restoring Legitimacy. Management Communication Quarterly, 26(2), 322-345.

Whittington, R. (2006). Completing the practice turn in strategy research.

Organization Studies, 27: 613-634.

Whittington, R. (2014). Information systems strategy and strategy-as-practice: a joint agenda. The Journal of Strategic Information Systems, 23(1), 87-91.

Whittington, R. (2015). The Massification of Strategy. British Journal of Management, 26(S1), S13-S16.

Withagen, R. et al. (2012). Affordances Can Invite Behavior: Reconsidering the Relationship Between Affordances and Agency. New Ideas in Psychology, 30(2): 250-258.

Woodward, J. (1958). Management and technology. London: Her Majesty's Stationary Office.

Xu, Z., Frankwick, G. L., and Ramirez, E. (2016). Effects of big data analytics and traditional marketing analytics on new product success: A knowledge fusion perspective. Journal of Business Research, 69(5), 1562-1566.

Yeow, A., Soh, C., and Hansen, R. (2017, September). Aligning with new digital strategy: A dynamic capabilities approach. Journal of Strategic Information Systems. Zammuto, R. F., Griffith, T. L., Majchrzak, A., Dougherty, D. J., and Faraj, S. (2007). Information Technology and the Changing Fabric of Organization. Organization Science, 18(5), 749-762. 


\section{Appendix 1: List of selected journals}

Search: Strategy

\begin{tabular}{|l|}
\hline Journals \\
\hline Strategic Management Journal \\
\hline Global Strategy Journal \\
\hline Long Range Planning \\
\hline Strategic Organization \\
\hline Advances in Strategic Management \\
\hline Journal of Economics and Management Strategy \\
\hline Strategic Change \\
\hline Technology Analysis and Strategic Management \\
\hline Business Strategy Review \\
\hline Foresight \\
\hline Journal of Change Management \\
\hline M@n@gement \\
\hline
\end{tabular}

Search: Organisation Studies

\begin{tabular}{|l|}
\hline Journals \\
\hline Organization Science \\
\hline Human Relations \\
\hline Leadership Quarterly \\
\hline Organization Studies \\
\hline Group and Organization Management \\
\hline Organization \\
\hline Research in Organizational Behavior \\
\hline Research in the Sociology of Organizations \\
\hline Culture and Organisations \\
\hline Group Dynamics: Theory, Research and Practice \\
\hline Group Processes and Intergroup Relations \\
\hline Journal of Knowledge Management \\
\hline Journal of Organizational Behavior Management \\
\hline Leadership \\
\hline Management Communication Quarterly \\
\hline
\end{tabular}

Search: Information Management

\begin{tabular}{|l|}
\hline Journals \\
\hline Information Systems Research \\
\hline MIS Quarterly \\
\hline Journal of Management Information Systems \\
\hline Journal of the Association of Information Systems \\
\hline European Journal of Information Systems \\
\hline Information and Management \\
\hline Information and Organization \\
\hline Information Society \\
\hline Information Systems Frontiers \\
\hline Information Systems Journal \\
\hline Information Technology and People \\
\hline
\end{tabular}




\begin{tabular}{|l|}
\hline International Journal of Electronic Commerce \\
\hline International Journal of Human-Computer Studies \\
\hline Journal of Computer Mediated Communication \\
\hline Journal of Information Technology \\
\hline Journal of Strategic Information Systems \\
\hline
\end{tabular}

Search: General Management, Ethics and social responsibility

\begin{tabular}{|l|}
\hline Academy of Management Journal \\
\hline Academy of Management Review \\
\hline Administrative Science Quarterly \\
\hline Journal of Management \\
\hline British Journal of Management \\
\hline Journal of Management Studies \\
\hline Academy of Management Perspectives \\
\hline Business and Society \\
\hline California Management Review \\
\hline European Management Review \\
\hline Harvard Business Review \\
\hline International Journal of Management Reviews \\
\hline Journal of Business Research \\
\hline Journal of Management Inquiry \\
\hline MIT Sloan Management Review \\
\hline Business Horizons \\
\hline Canadian Journal of Administrative Sciences \\
\hline
\end{tabular}




\section{Appendix 2: Systematic selection of relevant articles}

1) All selected articles were from journals from the ABS top-20 lists within the four most relevant disciplines. ${ }^{\text {vi }}$

2) A suitable database was chosen for each journal and a three-step search was conducted for each journal (in the 2000-2018 interval ${ }^{\mathrm{vii}}$ and in Englishlanguage articles).

3) The abstracts were searched for 'strategy' and at least one of the other search terms.

4) The titles were searched for 'strategy' and at least one of the other search terms.

5) The keywords and subject terms were searched for 'strategy' and at least one of the other search terms. ${ }^{\text {viii }}$

6) All searches were saved in the respective databases. All articles were saved in Mendeley. All articles were counted and duplicates were removed from the sample.

7) All abstracts were read and the clearly irrelevant articles were removed from the sample. 
Appendix 3: Article sample selection

\begin{tabular}{|c|c|c|}
\hline & \begin{tabular}{|l} 
Description \\
\end{tabular} & Number of results \\
\hline 1 & $\begin{array}{l}\text { Abstracts, keywords or title must } \\
\text { contain the word 'strategy', and the } \\
\text { article must be published in the } \\
\text { chosen journals }\end{array}$ & $\begin{array}{l}\text { General management: } 14,164 \\
\text { Information management: } 4,685 \\
\text { Organization: } 3,860 \\
\text { Strategy: } 4,575 \\
\text { Total: } 27,284\end{array}$ \\
\hline 2 & $\begin{array}{l}\text { The abstract, keywords or title must } \\
\text { also contain at least one of the } \\
\text { additional keywords. }\end{array}$ & $\begin{array}{l}\text { General management: } 483 \\
\text { Information management: } 218 \\
\text { Organization: } 193 \\
\text { Strategy: } 239 \\
\text { Total: } 1,133\end{array}$ \\
\hline 3 & Corrected for duplicates & $\begin{array}{l}\text { General management: } 177 \\
\text { Information management: } 221 \\
\text { Organization: } 113 \\
\text { Strategy: } 187 \\
\text { Total: } 698\end{array}$ \\
\hline 4 & $\begin{array}{l}\text { Limited the pool by reading abstracts } \\
\text { and removing clearly irrelevant } \\
\text { articles }\end{array}$ & $\begin{array}{l}\text { General management: } 54 \\
\text { Information management: } 37 \\
\text { Organization: } 6 \\
\text { Strategy: } 33 \\
\text { Total: } 130 \\
\end{array}$ \\
\hline
\end{tabular}


Appendix 4: Selected article overview (see separate file) 


\section{Endnotes}

${ }^{\mathrm{i}}$ The strategy list did not contain 20 impactful journals. Therefore, we selected all of the journals included in the strategy list.

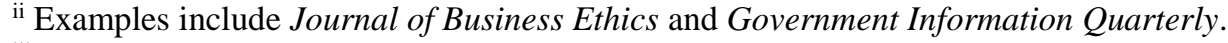

${ }^{\text {iii }} \mathrm{A}$ few of the journals were unavailable in certain years.

iv The number of keywords was too high to return accurate results if the search was done in one step, so we undertook separate searches as described. Therefore, the first step in each search still contained a high number of results. They emerge because the search is made in three steps that have overlapping results.

${ }^{\mathrm{v}}$ Examples of titles that were excluded: 'Technological entrepreneurship and capacity building in biotechnology', 'Why Facebook is a lot like Listerine', 'China and global ICT standardization and innovation' and 'Backpedalling to stay ahead of the game: Discursive institutional work in the deployment of digital terrestrial television in France'.

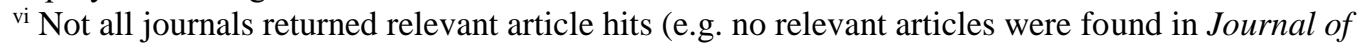
Economics and Management Strategy, Journal of Organisational Behavior Management or Research in Organisational Behavior).

vii Note that some journals are only accessible from 2000 (Journal of Change Management), 2002 (Culture and Organization), 2010 (M@n@gement and Foresight) and 2011 (Global Strategy Journal). Others do not have the most recent years available (e.g. Journal of Economics and Management Strategy).

viii We consider the abstract and title most important, as we view the mention of one of our search terms in these fields as an indicator of relevance. As the keywords or subject terms often depend on specific categories determined by the publisher, they may be less accurate. However, one of the search engines did not allow for searches of abstracts. Therefore, this part of the search was left out for some of the journals. 